\title{
The relationship between employees' competences and the consequences and manner of exercising emotional labour (EL)
}

\author{
Agnieszka Springer ${ }^{1}, K^{2}$ arolina Oleksa ${ }^{1}$
}

\begin{abstract}
Many job posts require one to display emotions specified by organisational standards. Such work is referred to as emotional labour (EL) and consists in producing particular emotional reactions in contacts with a customer as well as suppressing the actual emotional reactions that could be seen negatively by the other party. An employee may cope with such work by choosing one of two strategies: surface acting or deep acting. Emotional labour has various consequences, and professional burnout is among the negative ones. The objective of the article is to review the literature concerned with the exercise and the consequences of $E L$ and analyse the relationship between surface and deep acting and the level of professional burnout among selected professional groups ( $\mathrm{N}=297)$. Furthermore, the authors examine the correlation between an employee's competences and their preferred style of EL and assess the moderating role of competences in negative consequences of EL. Analyses confirm that the persons characterised by surface role-playing display a higher level of professional burnout; however, no correlation is found between deep role-playing and lower professional burnout. Analysis of the coefficients of correlation demonstrates no significant correlation between an employee's competences and deep acting, whereas a statistically significant correlation is discovered between competences and the surface strategy. The higher the competences, the less likely the employee will exercise surface acting. Verification of the last hypothesis reveals that people with a higher level of competences who follow the surface strategy in terms of faking emotions are characterised by a lower level of professional burnout than employees with lower competences.
\end{abstract}

KEY WORDS: $\quad$ emotional labour, surface role-playing, deep role-playing, professional burnout, professional competences

JEL Classification: J24, L80

${ }^{1}$ WSB University in Poznan, the Institute of Management, Poland

\section{Introduction}

The practical experiences of employees show that work $\underline{\underline{0}}$ is more and more commonly connected with display-

Correspondence concerning this article should be addressed to: Agnieszka Springer, WSB University in Poznan, the Institute of Management, ul. Powstańców Wielkopolskich 5, 61-895 Poznań, Poland. E-mail: agnieszka.springer@wsb.poznan.pl ing a certain type of emotion (Ashforth \& Humphrey, 1995; Hochschild, 2009). Organisations dictate to employees how to react emotionally with standard behaviours in relations with customers, specifying the manners of greeting, servicing standards, and complaint handling (Grandey, 2000). Such practices often cause the employees to find themselves in a situation where the emotions they feel do not correspond to the emo- 
tions they display (Morris \& Feldman, 1996; Szczygieł, Bazińska, Kadzikowska-Wrzosek, \& Retowski, 2009). Such work can give rise to both positive consequences, e.g., taking pride in or having high satisfaction with work (Jin \& Guy, 2009), and negative consequences connected with emotional exhaustion (Seery \& Corrigall, 2009), professional burnout (Babakus, Yavas, \& Ashill, 2011; Jin \& Guy, 2009), or lower commitment or absence from work (Chau, Dahling, Levy, \& Diefendorff, 2009). Enterprises that introduce behavioural standards regulating emotional reactions hope to produce positive effects such as customer satisfaction and loyalty as well as increased organisational revenue (Hwa, 2012) but underestimate the negative consequences of the phenomenon. The difficulty in evaluating the potential negative consequences of emotional labour arises from the existence of multiple moderating variables related to both persons and organisations. This analysis is focused on identifying the role of selected variables related to persons, including employees' competences. Until now, in addition to the most commonly analysed influence of emotional intelligence on the consequences of emotional labour (Rathi, 2014), research has stressed the role of personality variables (Brook, 2013), reaction styles (Groth, Hennig-Thurau, \& Walsh, 2009; Judge, Woolf, \& Hurst, 2009), effects (Judge et al., 2009), and the system of values (Diefendorff \& Gosserand, 2003). Identification of these variables is of immense importance in cognitive terms and contributes to a better understanding of the nature of a reaction, but it does not offer many possibilities for application in the practice of human resource management. The authors, however, see such a chance in indicating the dependencies between competences and the consequences of EL, as competences are more and more commonly used in recruitment, evaluation, or development of employees. Thus, the objective of the article is to indicate the role of competences in coping with emotional labour.

\section{Theoretical basis for the study}

\subsection{Emotional labour}

Looking after the client is a significant element of running a business; therefore, employees are required to meet numerous demands in terms of displaying emotions. An example is work as a client adviser, which requires an employee to adopt a positive attitude towards the client and to use impeccable manners and body expression to mask feelings and emotions that might negatively influence the client's opinion. Arousing and experiencing emotions is dependent on various social factors, and people generally strive to feel emotions that are in compliance with a given social situation and accepted norms (Hochschild, 1979). This is particularly visible in professional life (Ashforth \& Humphrey, 1995; Grandey, 2000; Hochschild, 2009), and in consequence employees endeavour to moderate their emotions adequately according to organisational requirements. Management of emotions as an element of one's role at work is referred to as emotional labour - which means that employees must show or suppress given feelings to create the impression that will evoke a desired state of the client's mind (Hochschild, 2009). Emotional labour is mainly the domain of employees in the service sector, as they represent the company in contacts with clients and interact frequently with clients (Hochschild, 2009; Morris \& Feldman, 1996; Rafaeli \& Sutton, 1990). However, emotions are also a significant part of work in the public sector, e.g., in public administration bodies where the level of bureaucratisation seems to be correlated with suppression of emotions (Vigoda-Gadot \& Meisler, 2010), and among people working in professions that require a certain relation to be built with a client, high moral standards to be demonstrated, and services to be of high quality, e.g., doctors, psychologists, nurses, or teachers (Bajcar, Borkowska, Czerw, \& Gąsiorowska 2011, p. 11). Various determinants may influence display of emotions, not only organisational requirements but also particularities of the client, such as their age, gender, or even social status (Rafaeli \& Sutton, 1990).

Analysing the spectrum of factors determining emotional labour, it may be concluded that it is an element that is present to some extent in any profession; however, some professions require particular devotion to emotional labour, which prompts employees to adopt a strategy of emotion regulation. Hochschild (1979) presumes that workers may achieve this in two ways: by deceiving others in playing an appropriate role or by convincing both others and oneself of genuine experience of the required emotions. These strategies are respectively referred to as surface acting and deep acting or role-playing (Hochschild, 1979). Sur- 
face acting consists in limiting emotion management to exclusively displaying an emotion without experiencing it. A shop assistant will smile at a demanding customer while masking irritation, and a prison guard will show power and dominance with verbal expression and posture while in fear of a prison riot. In both cases, the employees merely camouflage their true feelings. Deep acting is more complex than surface acting, as in deep acting an employee puts effort into feeling the emotion that is appropriate in a given situation.

Emotion management through surface and deep acting brings about various consequences, both positive and negative (Grandey, 2000). Research demonstrates that surface acting is correlated with the sense of tiredness and isolation because it requires greater energy to correct feelings and constantly monitor and mask one's emotions (Brotheridge \& Grandey, 2002; Gradney, 2000; Hülsheger \& Schewe, 2011). Furthermore, in comparison to deep acting, surface acting creates greater difficulty in maintaining positive emotions in the face of stress provoked by the discord between true and presented feelings, which is reflected by a higher level of exhaustion and a less positive assessment of one's own work (Totterdell \& Holman, 2003). Emotional labour is also correlated with the level of authenticity of emotion - surface acting lowers the level of authenticity, whereas research has shown no such correlation in the case of deep acting (Hülsheger \& Schewe, 2011). As Brotheridge and Gardney (2002) conclude: although both surface and deep acting allow employees to express the emotions desired by the organisation, the physiological state produced by the actual emotions felt remains, which may negatively influence employee health and level of stress. The effect of such influence may be the emergence of professional burnout in an employee affected by emotional labour (Babakus et al., 2011; Brotheridge \& Grandey, 2002; Grandey, 2003; Hochschild, 2009; Hülsheger \& Schewe, 2011, Hwa, 2012; Jin \& Guy, 2009, Maslach, Schaufeli \& Leiter, 2001; Seery \& Corrigall, 2009, Zapf, Seifert, Schmutte, \& Mertini, \& Holz, 2001).

\subsection{Negative consequences of emotional labour - professional burnout}

The phenomenon of professional burnout has been studied since the 1970s. It has been discussed mainly in the context of service professions following the cultural transformations in the 1960s, when clients started to demand greater care, empathy, and emotional input from employees but did not reciprocate their efforts, which amplified the feeling of exhaustion and lack of appreciation (Schaufeli, Leiter \& Maslach, 2009). It is believed that because of the article by Herbert Freudenberger - one of the pioneers in research on burnout - this set of symptoms acquired the name professional burnout (Sęk, 2004, p. 7). Dynamic development of the concept of professional burnout took place owing to the research and publications of the American psychologist Christina Maslach, among others, who not only created a theoretical model of burnout but also co-authored a tool serving to measure it. Maslach and Jackson (1984) defined professional burnout with a threefactor model including a psychological syndrome of emotional exhaustion, depersonalisation, and lower opinion of one's personal achievements, which may appear in people working with other people. They call the sense of emotional overburdening accompanied by a simultaneous shortage of emotional resources emotional exhaustion. Depersonalisation is negative and often seen in reaction to people who are usually clients or subordinates of the person suffering from professional burnout, whereas a low opinion of one's personal achievements is related to a low opinion of one's competences and successes at work (Maslach \& Jackson, 1984; Maslach et al., 2001). Another researcher, Demerouti, Bakker, Nachreiner and Schaufeli (2001) proposed a model of professional burnout consisting of two dimensions: exhaustion, i.e., general tiredness, bad mood, and fear in reaction to organisational stress, and loss of commitment, i.e., withdrawal from one's work owing to difficulty in meeting professional requirements.

Professional burnout seems to be a threat to any employee because the factors causing this syndrome to emerge are varied and common. However, practice demonstrates that some professional groups are more susceptible to burnout, e.g., where employees maintain contacts with other people, such as clients, patients, and subordinates (Jenkins \& Maslach, 1994; Schaufeli et al., 2009). Among the factors correlated with the level of professional burnout are emotional stressors resulting from working with people, including, among others, the requirement to show or 
suppress some emotions and be empathic towards the client (Maslach et al., 2001; Zapf et al., 2001). Variables related to emotional labour partially correspond to organisational variables that are stressors influencing professional burnout, e.g., emotional labour is connected to time pressure placed on establishing positive relations with clients (Zapf et al., 2001). In such cases, the manner of coping with emotional labour, i.e., reacting through surface or deep acting, may be seen as a determinant of the symptoms of professional burnout. The two styles interact differently with each of the three factors contributing to burnout: the syndrome of emotional exhaustion, depersonalisation, and lower opinion of one's personal achievements.

Research has confirmed the hypothesis that surface role-playing coexists with emotional exhaustion, whereas there is no such relation in the case of deep acting (Grandey, 2003; Hwa, 2012; Judge, Woolf \& Hurst, 2009; Morris, Feldman, 1996; Seery \& Corrigall, 2009). Although deep acting requires energy to be put into feeling the desired emotions, it lowers the emotional distance between the state one experiences and the one that is presented and additionally correlates with a greater number of authentic, positive reactions from the clients, which is rewarding for the employee engaged in emotional labour (Gardney, 2003). Furthermore, surface role-playing coexists with distancing oneself from the client - people who mask their true emotions and portray other emotions begin to treat the client like an object, which makes it easier for them to feign emotions (Brotheridge \& Gardney, 2002). Such distancing from the client and deception through expressed emotions may cause negative feelings towards oneself, which indicates that surface acting is significantly correlated with a lower opinion of one's achievements and decreased commitment towards the organisation (Brotheridge \& Gardney, 2002; Hochschild, 2009; Zapf et al., 2001). Based on analysis of the relevant literature, the authors put forward two hypotheses concerning professional burnout and the manner of acting in emotional labour:

H1: People who adopt the strategy of surface acting in emotional labour show a higher level of professional burnout.
H2: People who adopt the strategy of deep acting in emotional labour show a lower level of professional burnout.

Because the syndrome of professional burnout brings about serious consequences for the psychological and physical balance of an employee, which affects their effectiveness and the success of an organisation, it is worth analysing the factors that might reduce the negative influence of the stressors and other consequences arising from emotional labour. The authors presume that such factors can be employees' competences, whose application may allow effective management of one's emotions in the workplace.

\subsection{Employee Competences}

Competences have been present in the practice and theory of human resource management for over 40 years. In understanding the significance of competences seen as the internal potential of an employee, the publications by D. C. McClelland and his follower R. E. Boyatzisa have been groundbreaking (Boyatzis, 1982; 2008; McClelland \& Boyatzis, 1980; McClelland, 1973). These authors first stress the relationship between an employee's effectiveness in a given post and his internal predispositions. Boyatzis defines competences as "the potential, existing within the human, leading to such a behaviour that helps to satisfy the requirements at a given post" (Boyatzis, 1982, p. 18). Competences are most commonly treated as a collection of three components: knowledge, skills, and attitudes (Kossowska \& Sołtysińska, 2002; SidorRządkowska, 2006; Thierry, Monod, \& Sauret, 1994, p. 90); however, they may also include motivation, personality traits, values, self-esteem, and social role (Spencer \& Spencer, 1993). As Dubois and Rothwel put it, defining competences moves towards including each trait of an individual that allows them to achieve the expected results in a given post (Dubois \& Rothwel, 2008, p. 32). In the present analysis, competences are treated as a collection of knowledge, skills, and attitudes, whereas personality traits or motivation are rather the conditions for building and manifesting competences and not the competences themselves.

The American approach to competences focuses on universal models of the most effective managers and person-related conditioning of effectiveness, 

Table 1. Structure of the group under examination according to gender, age, and education

\begin{tabular}{llcc}
\hline & & Size & $\%$ \\
\hline \multirow{3}{*}{ Gender } & Male & 205 & $69.3 \%$ \\
\cline { 2 - 4 } & Total & 91 & $30.7 \%$ \\
\hline $18-26$ & 296 & $100.0 \%$ \\
\hline \multirow{4}{*}{ Age } & $79-35$ & 79 & $26.7 \%$ \\
& $36-45$ & 53 & $29.4 \%$ \\
& $46-55$ & 66 & $17.9 \%$ \\
& Above 55 years old & 11 & $22.3 \%$ \\
\cline { 2 - 4 } Vocational education & Total & 296 & $3.7 \%$ \\
\hline & Junior high school & 13 & $100.0 \%$ \\
\hline & Secondary & 71 & $4.4 \%$ \\
\cline { 2 - 4 } & Higher & 212 & $24.0 \%$ \\
\cline { 2 - 4 } & Total & 296 & $71.6 \%$ \\
\hline
\end{tabular}

ments regarding activities during a typical day at work. The respondents are asked to estimate on a five-point scale (ranging from "never" to "always") to what extent they agree with a given statement.

Professional burnout was measured with a translated OLBI questionnaire developed by Demerouti and her co-workers (Demerouti et al., 2003) OLBI encompasses the affective, physical, and cognitive aspects of exhaustion. The questionnaire measures two dimensions: exhaustion and lack of commitment. Each subscale contains four items phrased positively and four phrased negatively (Demerouti et al., 2003). The questionnaire is composed of 16 statements regarding feelings and behaviours related to work. The respondent determines the level to which they agree with a given statement on a four-point scale from "completely agree" to "completely disagree". The Polish adaptation of the test was made by Teresa Chirkowska-Smolak (in press) on a group of 664 respondents.

Evaluation of competences was performed with a self-assessment questionnaire composed of 36 descriptions of various skills of an employee. These skills were grouped into a model consisting of six basic competences characteristic of various areas of professional operation. Employees evaluated all the items on a 5-point scale from 1: "I absolutely cannot do it" to 5: "I can do it really well".

\section{Research results}

Eleven variables are analysed in the study, three of which characterized emotional labour, two professional burnout, and six competences. The reliability of all the scales is verified with the Cronbach's alpha coefficient, indicating the integrity of the adopted tool. The coefficients for all the adopted scales have satisfactory values and are comparable to the results obtained in other studies (see table 2). Simultaneously, all the variables obtained in the scales under analysis have a normal distribution.

The respondents are characterised by a similar level of deep emotional labour and score in the scale of hiding feelings. The scores in the scale of faking feelings are a little higher. It is worth stressing that the results describing emotional labour and the mean, and the 
Table 2. Evaluation of the reliability of the adopted scales with the Cronbach's alpha coefficient

\begin{tabular}{lcc}
\hline Scale & Number of items & Cronbach's alpha \\
\hline Deep acting & 3 & 0.66 \\
Surface acting - hiding emotions & 3 & 0.79 \\
Surface acting - faking emotions & 3 & 0.64 \\
Lack of commitment & 8 & 0.64 \\
Exhaustion & 8 & 0.75 \\
Dominance & 9 & 0.84 \\
Being organized & 6 & 0.76 \\
Focusing on information & 6 & 0.73 \\
Focusing on emotions & 5 & 0.68 \\
Analysis and use of facts & 6 & 0.77 \\
Imaginativeness and openness & 4 & 0.72 \\
\hline
\end{tabular}

differences in professional burnout are similar to the ones obtained in other studies carried out on Polish workers with the use of the same tools. The situation is slightly different when it comes to competences, as in this case the mean results are a little higher and differences are lower than those in research using the same tools conducted on a representative sample of people working in the Wielkopolskie Voivodeship. The above score is, however, amply justified and results from the structure of the sample under examination, where $70 \%$ of the respondents are people with higher education. Indeed, earlier research showed that education is a variable that significantly differentiates the level of competences.

Analysis of the interdependencies among the variables under analysis (see table 3 ) shows no correlation between the deep strategy of emotional labour and the indicators of professional burnout, while the surface strategy does show influence on professional burnout.

With the median score in individual scales of emotional labour adopted as the point of division, assessment of the significance of differences in terms of an employee's lack of commitment and exhaustion has been performed. T-test confirms that people with a higher level of surface acting (in the contexts of hid- ing and faking emotions) are also marked by a higher level of professional burnout. No such correlation has been found concerning deep acting (see table 4).

The above results confirm the first hypothesis that people who adopt the surface strategy of emotional labour display a higher level of professional burnout. At the same time, no grounds have been found to support the second proposed hypothesis that people exercising a higher level of deep acting show a lower level of professional burnout.

Another question asked in the paper concerns the influence of one's competences on the way emotional labour is handled. Analysis of the coefficients of correlation demonstrates no dependencies between employees' competences and the intensity of deep acting. Simultaneously, there is a statistically significant correlation between competences and surface acting observable in many cases. It is thus worth highlighting that this relation is inversely proportional, and hence the higher the level of competences, the less likely the employee will undertake surface acting. Comparison of employees with low and high levels of competences within a given competence cluster (with the median of the obtained scores as the point of division) reveals that employees who are highly organized, focused on 
Table 3. Descriptive statistics and r-Spearman's correlation coefficients for the variables under analysis

\begin{tabular}{|c|c|c|c|c|c|c|c|c|c|c|c|c|c|}
\hline \multirow[b]{2}{*}{ Variables } & \multirow[b]{2}{*}{$M$} & \multirow[b]{2}{*}{ SD } & \multicolumn{11}{|c|}{ Coefficients of correlation } \\
\hline & & & 1 & 2 & 3 & 4 & 5 & 6 & 7 & 8 & 9 & 10 & 11 \\
\hline PG & 2.85 & 0.810 & 1 & & & & & & & & & & \\
\hline PP hiding & 2.82 & 0.809 & .082 & 1 & & & & & & & & & \\
\hline PP faking & 2.49 & 0.781 & $.139^{*}$ & $.628^{* *}$ & 1 & & & & & & & & \\
\hline $\begin{array}{l}\text { Lack of } \\
\text { commitment }\end{array}$ & 2.38 & 0.448 & -.060 & $.308^{* *}$ & $.273^{* *}$ & 1 & & & & & & & \\
\hline Exhaustion & 2.48 & 0.447 & -.055 & $.274^{* *}$ & $.251^{* *}$ & $.657^{* *}$ & 1 & & & & & & \\
\hline Dominance & 3.59 & 0.589 & .034 & $-192^{* *}$ & -.077 & $-.122^{*}$ & -.101 & 1 & & & & & \\
\hline $\begin{array}{l}\text { Being } \\
\text { organizededed }\end{array}$ & 3.90 & 0.572 & .032 & $-.154^{* *}$ & -.102 & $-.125^{*}$ & $-.191^{* *}$ & $.655^{* *}$ & 1 & & & & \\
\hline Information & 3.85 & 0.642 & .013 & $-.125^{*}$ & -.044 & -.032 & -.077 & $.655^{* *}$ & $.580^{* *}$ & 1 & & & \\
\hline Emotions & 3.98 & 0.573 & .017 & -.097 & -.066 & $-.161^{* *}$ & $-.133^{*}$ & $.638^{* *}$ & $.615^{* *}$ & $.536^{* *}$ & 1 & & \\
\hline Facts & 3.88 & 0.574 & .024 & $-.188^{* *}$ & $-.145^{*}$ & $-.153^{* *}$ & $-.194^{* *}$ & $.700^{* *}$ & $.727^{* *}$ & $.632^{* *}$ & $.704^{* *}$ & 1 & \\
\hline Openness & 3.81 & 0.647 & .103 & $-.156^{* *}$ & -.083 & -.096 & -.044 & $.715^{* *}$ & $.574^{* *}$ & $.618^{* *}$ & $.675^{* *}$ & $.693^{* *}$ & 1 \\
\hline
\end{tabular}

Note: ${ }^{*} p<0.05,{ }^{* *} p<0.01$

Table 4. Analysis of the significance of differences among the mean scores in the scale of professional burnout among the subgroups under examination.

\begin{tabular}{|c|c|c|c|c|c|c|c|}
\hline $\begin{array}{l}\text { Independent } \\
\text { variable }\end{array}$ & M1 & SD1 & M2 & SD2 & $\mathbf{t}$ & df & $\begin{array}{l}\text { two-tailed } \\
\text { significance }\end{array}$ \\
\hline & \multicolumn{2}{|c|}{ high deep acting } & \multicolumn{2}{|c|}{ low deep acting } & & & \\
\hline Lack of commitment & 2.3324 & .46768 & 2.4288 & .42297 & -1.863 & 293.376 & 0.063 \\
\hline \multirow[t]{2}{*}{ Exhaustion } & 2.4449 & 0.4524 & 2.5087 & 0.4414 & -1.228 & 293.739 & 0.221 \\
\hline & \multicolumn{2}{|c|}{ PP-hiding - high } & \multicolumn{2}{|c|}{ PP-hiding - low } & & & \\
\hline Lack of commitment & 2.5122 & 0.4290 & 2.2550 & 0.4313 & 5.142 & 292.855 & 0.000 \\
\hline \multirow[t]{2}{*}{ Exhaustion } & 2.6075 & 0.4576 & 2.3529 & 0.4018 & 5.072 & 283.054 & 0.000 \\
\hline & \multicolumn{2}{|c|}{ PP-faking - high } & \multicolumn{2}{|c|}{ PP-faking - low } & & & \\
\hline Lack of commitment & 2.4676 & 0.4528 & 2.3011 & 0.4309 & 3.231 & 285.591 & 0.001 \\
\hline Exhaustion & 2.5522 & 0.4489 & 2.4084 & 0.4366 & 2.785 & 287.526 & 0.006 \\
\hline
\end{tabular}


Table 5. Level of significance of the differences in terms of hiding and faking emotions among employees with high and low levels of competences from a given cluster

\begin{tabular}{lcc}
\hline Competence cluster & PP - hiding & PP - faking \\
\hline dominance & .143 & .430 \\
being organized & .042 & .198 \\
information & .001 & .075 \\
emotions & .440 & .236 \\
facts & .004 & .012 \\
openness & .009 & .161 \\
\hline
\end{tabular}

Table 6. Level of significance of the differences between the mean scores in the scales of professional burnout and the selected groups of employees.

\begin{tabular}{lcccc}
\hline \multirow{2}{*}{ Analysed variables } & \multicolumn{2}{c}{ Employees with low competences } & \multicolumn{2}{c}{ Employees with high competences } \\
\cline { 2 - 4 } & Lack of commitment & Exhaustion & Lack of commitment & Exhaustion \\
\hline Deep acting & 0.031 & 0.190 & 0.649 & 0.832 \\
$\begin{array}{l}\text { Surface acting - } \\
\text { Hiding feelings }\end{array}$ & 0.000 & 0.001 & 0.002 & 0.001 \\
$\begin{array}{l}\text { Surface acting - } \\
\text { Faking emotions }\end{array}$ & 0.004 & & & 0.128 \\
\hline
\end{tabular}

information and analysis of facts, imaginative and open hide their emotions less frequently. At the same time, employees with higher focus on analysis and use of facts are less likely to fake their emotions during contacts with clients.

Considering the results of the above analyses, which indicate that competences are correlated with the strategy of emotional labour to a limited extent, it has been decided that the third hypothesis, that competences influence the way emotional labour is exercised, can only partially be supported. As research demonstrates, competences exert influence on hiding emotions exclusively.

The last research question is concerned with the moderating influence of competences on the emergence of the negative effects of emotional labour. Two groups of employees have been singled out for that purpose: the groups of people with lower $(\mathrm{N}=147)$ and higher $(\mathrm{N}=178)$ levels of competences. The analysis reveals that the negative consequences of surface acting, namely lack of commitment, are less common among employees with higher competence levels. Simultaneously, the level of competences determines whether faking emotions will bring about negative consequences in the form of professional burnout. The analysis confirms that people with a higher level of competences who follow the surface strategy by faking emotions are characterised by a lower level of professional burnout than employees with low competences. It is worth stressing that putting effort into faking emotions has negative consequences such as professional burnout regardless of the level of an employee's competences (see table 6). 
Analogously to hypothesis 3 , the above results only allow partial acceptance of hypothesis 4 , that in the group of employees exercising surface acting in emotional labour, those with higher competences show lower levels of professional burnout. This hypothesis may only be supported with regard to surface acting through faking emotions.

\section{Discussion of the results}

The objective of this study was to verify four hypotheses regarding correlations among the variables: deep and surface acting in emotional labour, the level of professional burnout, and the level of competences. First, the correlations between surface and deep roleplaying and the level of professional burnout were examined. In accordance with the results of international research (Gardney, 2003; Hwa, 2012; Judge et al., 2009; Morris, \& Feldman, 1996; Seery \& Corrigall, 2009; Totterdell, \& Holman, 2003), analyses have demonstrated that surface role-playing is correlated with a higher level of professional burnout, whereas there is no such correlation in the case of deep acting. As initially presumed, surface acting requires greater effort to be put into correcting feelings and monitoring one's emotions, which influences the sense of exhaustion that is a component of burnout (Brotheridge \& Grandey, 2002; Gradney, 2000; Hülsheger \& Schewe, 2011). Moreover, surface acting requires maintaining distance from clients and deceiving them though the expression of appropriate emotions, which results in lower commitment to doing one's job (Brotheridge \& Gardney, 2002; Hochschild, 2009; Zapf at al., 2001). Studies have not confirmed the existence of a correlation between deep acting and a lower level of professional burnout, although such an opinion can be found in the relevant literature (Gardney, 2003; Hülsheger, \& Schewe, 2011).

Second, the hypothesis that an employee's competences differentiate the style of emotional labour (i.e., surface or deep acting) was verified. Six competence clusters were singled out in the study, and tests were performed to determine whether these clusters differentiate the selected style of emotional labour. Analysis of the coefficients of correlation demonstrated no dependencies between employees' competences and deep acting. It was particularly surprising to find that there is no significant correlation between compe- tences connected with application of emotions, which is inconsistent with previous research that indicated that emotional intelligence influenced deep acting (Rathi, 2014). Simultaneously, a statistically significant correlation was noted between competences and the adoption of the surface strategy - the higher the level of competences, the less likely the employee would undertake surface acting. The above result may arise from the fact that persons characterised by a higher level of competences have greater self-confidence, are thus less worried about the consequences of displaying their emotions, and resort less often to hiding or faking emotions.

The final hypothesis assumed that employees with higher competences experience fewer negative consequences of emotional labour. The analyses that were conducted revealed that people with a higher level of competences that follow the surface strategy by faking emotions are characterised by a lower level of professional burnout than employees with a lower level of competences. It has simultaneously been proven that putting effort into faking emotions has negative consequences such as higher professional burnout regardless of the level of an employee's competences.

The above result may arise from the effort that employees must put into maintaining positive emotions in the face of stress caused by a discord between the actual and presented states of mind, which, independently from other variables, increases the sense of exhaustion and lowers the opinion of one's own work (Totterdell \& Holman, 2003).

\section{Conclusions and recommendations}

The obtained results show that surface acting in emotional labour coexists with a higher level of professional burnout. This has serious consequences for employees and the company because professional burnout involves lower commitment to one's work and higher exhaustion, which usually results in decreased effectiveness. It is thus worth analysing the organisational requirements that cause employees to hide or fake emotions. Analysis of competences and confirmation of the existence of correlations between higher levels of individual competence clusters and lower levels of hiding or faking emotions may hold practical implications for the recruitment process. During recruitment for the posts where emotional labour is a must, it is 
worth checking the candidate's competences in individual competence groups. It is also worth considering the possibility of training employees engaged in emotional labour to develop given competences and prevent professional burnout. The authors are aware of the limitations of the presented study, which are concerned with the selection and size of the sample and the use of self-assessment to diagnose the level of competences. This study uses a self-reporting tool, which means that evaluation of competences might have been subjective and dependent, e.g., on the level of self-esteem or the respondent's experience. To verify the research results, it is advisable that the sample of the respondents be increased and more objective methods be used to diagnose employee competences. Analyses may also be carried out based on a division of the respondents in terms of job type, e.g., related to education or trade. This would allow analysis of the manner of coping with emotional labour, the level of professional burnout, and the competences of employees in a given profession.

\section{References}

Ashforth, B. E., \& Humphrey, R. H. (1995). Emotion in the workplace: A reappraisal. $H u$ man Relations, 48(2), 97-125. http://dx.doi. org/10.1177/001872679504800201

Babakus, E., Yavas, U., \& Ashill, N. J. (2011). Service worker burnout and turnover intentions: Roles of person-job fit, servant leadership, and customer orientation. Services Marketing Quarterly, 32(1), 17-31. http://doi.org/10.1080/15332969.2011.53 3091

Bajcar, B., Borkowska, A., Czerw, A., \& Gąsiorowska, A. (2011). Satysfakcja $z$ pracy $w$ zawodach $z$ misja społeczna. Psychologiczne uwarunkowania [Job Satisfaction in professions with social mission. Psychological determinants]. Gdańsk: Gdańskie Wydawnictwo Psychologiczne.

Boak, G., \& Coolican, D. (2001). Competencies for retail leadership: accurate, acceptable, affordable. Leadership \& Organization Development Journal, 22(5), 212-220. http://doi.org/10.1108/ EUM0000000005675

Boyatzis, R. E. (1982). The competent manager: A model for effective performance. New York, NY: John Wiley \& Sons.
Boyatzis, R. E. (2008). Competencies in the 21st century. Journal of Management Development, 27(1), 5-12. http://doi.org/10.1108/02621710810840730

Brotheridge, C. M., \& Grandey, A. A. (2002). Emotional labor and burnout: Comparing two perspectives of "people work". Journal of Vocational Behavior, 60(1), 17-39. http:/doi.org/10.1006/ jvbe.2001.1815

Brotheridge, C.M., \& Lee, R.T. (2003). Development and validation of emotional labour scale. Journal of Occupational and Organizational Psychology, 76(3), 365-379. http://dx.doi. org/10.1348/096317903769647229

Brook, P. (2013). Emotional labour and the living personality at work: Labour power, materialist subjectivity and the dialogical self. Culture \& Organization, 19(4), 332-352. http://doi.org/10.1080/147 59551.2013 .827423

Chau, S. L., Dahling, J. J., Levy, P. E., \& Diefendorff, J. M. (2009). A predictive study of emotional labor and turnover. Journal of Organizational Behavior, 30(8), 839-862. http://doi.org/10.1002/job

Chirkowska-Smolak, T. (in press). Polska adaptacja kwestionariusza do pomiaru wypalenia zawodowego OLBI (Oldenburg Burnout Inventory), [The Polish adaptation of Oldenburg Burnout Inventory] Studia Oeconomica Posnaniensia, 5.

Demerouti, E., Bakker, A. B. , Nachreiner, F. , \& Schaufeli, W. B. (2001) The job demands- resources model of burnout. Journal of Applied Psychology, 86(3), 499-512. http://dx.doi.org/10.1037/00219010.86.3.499

Demerouti, E., Bakker, A. B., Vardakou, I., \& Kantas, A. (2003). The convergent validity of two burnout instruments: A multitrait-multimethod analysis. European Journal of Psychological Assessment, 19(1), 12-23. http://doi.org/10.1027//10155759.19.1.12

Diefendorff, J. M., \& Gosserand, R. H. (2003). Understanding the emotional labor process: a control theory perspective. Journal of Organizational Behavior, 24(8), 945-959. http://doi.org/10.1002/ job. 230

Dubois, D. D., \& Rothwel, W. J. (2008). Zarządzanie zasobami ludzkimi oparte na kompetencjach [Competency-based human resource management]. Gliwice: Wydawnictwo Helion. 
Filipowicz, G. (2004). Zarządzanie kompetencjami zawodowymi [Management based on professional competence]. Warszawa: PWE.

Finogenow, M., Wróbel, M., \& Mróz, J. (2015). Skala Płytkiej i Głębokiej Pracy Emocjonalnej (SPGPE) - adaptacja narzędzia i analiza własności psychometrycznych [Deep acting and surface acting scale (DASAS) - Adaptation of the method and analysis of psychometric properties]. Medycyna Pracy, 66(3), 359-371. http://dx.doi.org/10.13075/ mp.5893.00168

Garavan, T. N., \& McGuire, D. (2001). Competencies and workplace learning: Some reflections on the rhetoric and the reality. Journal of Workplace Learning, 13(3-4), 144-164. http://doi. org/10.1108/13665620110391097

Grandey, A. A. (2000). Emotional regulation in the workplace: A new way to conceptualize emotional labor. Journal of Occupational Health Psychology, 5(1), 95-110. http://doi.org/10.1037//10768998.5.1.95

Grandey, A. A. (2003). When "the show must go on": Surface acting and deep acting as determinants of emotional exhaustion and peer-rated service delivery. Academy of Management Journal, 46(1), 86-96. http://dx.doi.org/10.2307/30040678

Groth, M., Hennig-Thurau, T., \& Walsh, G. (2009). Customer reactions to emotional labor: The roles of employee acting strategies and customer detection accuracy. Academy of Management Journal, 52(5), 958-974. http://dx.doi.org/10.5465/ AMJ.2009.44634116

Hochschild, A. (1979). Emotion work, feeling rules, and social structure. American Journal of Sociology, 85(3), 551-575. http://doi.org/10.1086/227049

Hochschild, A. R. (2009). Zarządzanie emocjami. Komercjalizacja ludzkich uczuć [The Managed heart: Comercialization of Human Feeling]. Warszawa: PWN.

Hülsheger , U. R., \& Schewe, A. F (2011). On the costs and benefits of emotional labor: A meta-analysis of three decades of research. Journal of Occupational Health Psychology, 16(3), 361-389. http:// doi.org/10.1037/a0022876

Hwa, M. A. C. (2012). Emotional labor and emotional exhaustion: Does co-worker support matter? Journal of Management Research, 12(3),
115-127. http://search.proquest.com/openview/ d3042ca6da7d85f05fc3c66159079f5a/1 ?pqorigsite $=$ gscholar $\& \mathrm{cbl}=55395$

Jin, M. H., \& Guy, M. E. (2009). How emotional labor influences worker pride, job satisfaction, and burnout: An examination of consumer complaint workers. Public Performance \& Management Review, 33(1), 88-105. http://doi.org/10.2753/ pmr1530-9576330104

Jenkins, S. R., \& Maslach, C. (1994). Psychological health and involvement in interpersonally demanding occupations: A longitudinal perspective. Journal of Organizational Behavior, 15 (2), 101127. http://dx.doi.org/10.1002/job.4030150202

Judge, T. A., Woolf, E. F., \& Hurst, C. (2009). Is emotional labor more difficult for some than for others? A multilevel, experience-sampling study. Personnel Psychology, 62(1), 57-88. http://doi. org/10.1111/j.1744-6570.2008.01129.x

Kossowska, M., \& Sołtysińska, I. (2002). Szkolenia pracowników a rozwój organizacji [Employee training and organizational development]. Kraków: Oficyna Ekonomiczna.

Maslach, C., \& Jackson, S. E. (1984). Burnout in organizational settings. In S. Oskamp (Ed.), Applied Social Psychology Annual: Applications in Organizational Settings (Vol. 5, pp. 133-153). Beverly Hills, CA: Sage.

Maslach, C., Schaufeli, W. B., \& Leiter, M. P. (2001). Job burnout. Annual Review of Psychology, 52, 397-422. http://doi.org/10.1146/annurev.psych.52.1.397

McClelland, D. C. (1973). Testing for competence rather than for „intelligence”. The American Psychologist, 28(1), 1-14. http://dx.doi.org/10.1037/h0034092

McClelland, D. C., \& Boyatzis, R. E. (1980). Opportunities for counselors from the competency assessment movement. Journal of Counseling and Development, 58(5), 368- 372. http://doi. org/10.1002/j.2164-4918.1980.tb00415.x

Morris, J. A., \& Feldman, D. C. (1996). The Dimensions, antecedents, and consequences of emotional labor. Academy of Management Review, 21(4), 986-1010. http://doi.org/10.5465/ AMR.1996.9704071861

Oleksyn, T. (2006). Zarządzanie kompetencjami. teoria i praktyka [Competency-based management. Theory and practice]. Kraków: Oficyna Ekonomiczna. 
Rafaeli, A., \& Sutton, R. I. (1990). Busy stores and demanding customers: How do they affect the display of positive emotion? Academy of Management Journal, 33(3), 623-637. http://doi. org/10.2307/256584

Rathi, N. (2014). Impact of emotional intelligence and emotional labor on organizational outcomes in service organizations: A conceptual model. South Asian Journal of Management, 21(4), 54-71. https://www.econbiz.de/Record/impact-of-emotional-intelligence-and-emotional-labor-on-organizational-outcomes-in-service-organizationsa-conceptual-model-rathi-neerpal/10010519710

Seery, B. L., \& Corrigall, E. A. (2009). Emotional labor: links to work attitudes and emotional exhaustion. Journal of Managerial Psychology, 24(8), 797-813. http://doi.org/10.1108/02683940910996806

Sęk, H. (2004). Wypalenie zawodowe. Przyczyny i zapobieganie [Professional burnout. Causes and prevention]. Warszawa: Wydawnictwo PWN.

Sidor-Rządkowska, M. (2006). Kompetencyjne systemy ocen pracowników [Competency- based employee appraisal systems]. Kraków: Oficyna Ekonomiczna.

Sienkiewicz, Ł. \& Trawińska-Konador, K. (2013). Koncepcja zarządzania zasobami ludzkimi w oparciu o kompetencje [Concept of competency-based human resource management]. In $€$. Sienkiewicz (Eds.), Zarządzanie zasobami ludzkimi w oparciu o kompetencje: Perspektywa uczenia się przez całe życie [Competency-based human resource management : lifelong learning perspective] (pp. 7-18). Warszawa: Instytut Badań Edukacyjnych.

Schaufeli, W. B., Leiter, M. P., \& Maslach, C. (2009). Burnout: 35 years of research and practice. Career Development International, 14(3), 204-220. http:// dx.doi.org/10.1108/13620430910966406

Spencer, L. M., \& Spencer, S. M. (1993). Competence at work: Models for superior performance. New York, NY: John Wiley \& Sons.

Springer, A. (2011). Problemy definiowania i klasyfikowania kompetencji pracowników [Problems of defining and classifying employees' competence]. Zeszyty Naukowe Wyższej Szkoły Bankowej w Poznaniu, 34, 249-260. http://jml.indexcopernicus.com/search/article/1437537

Szczygieł, D., Bazińska, R., Kadzikowska-Wrzosek, R., \& Retowski, S. (2009). Praca emocjonalna w za- wodach usługowych - pojęcie, przegląd teorii i badań [ Emotional labor in service work- theory and research review]. Psychologia Społeczna, 3(11), 155- 166. http://www.spoleczna.psychologia.pl/ pliki/2009_3/Szczygiel_PS_2009_3.pdf

Thierry, D., Monod, N., \& Sauret, C. (1994). Zatrudnienie i kompetencje $w$ przedsiębiorstwie $w$ procesach zmian [Employment and competence in enterprise during change process]. Warszawa: Poltex.

Totterdell, P., \& Holman, D. (2003). Emotion regulation in customer service roles: Testing a Model of Emotional Labor. Journal of Occupational Health Psychology, 8(1), 55-73. http://dx.doi. org/10.1037/1076-8998.8.1.55

Vigoda- Gadot, E., \& Meisler, G. (2010). Emotions in management and the management of emotions: The impact of emotional intelligence and organizational politics on public sector employees. Public Administration Review, 70(1), 72-86. http://doi. org/10.1111/j.1540-6210.2009.02112.x

Wood, R. (2006). Metody rekrutacji i selekcji pracowników oparte na kompetencjach [Competency-based recruitment and selection]. Kraków: Oficyna Ekonomiczna.

Zapf, D., Seifert, C, Schmutte, B, \& Mertini, H., Holz, M. (2001). Emotion work and job stressors and their effects on burnout. Psychology in Health, 16(5), 527-545. http://doi. org/10.1080/08870440108405525 
